\title{
International Theatre Festival in Jerusalem, November 23-26, 2008
}

\section{Nora Glickman}

Since 1993 the "Thespis Jerusalem International Festival for the Performers of Tomorrow" has hosted a large number of troupes from Europe and from the Americas. Although the 2008 festival was originally planned as a larger event, it was curtailed by a strike at the Hebrew University and by organizational problems resulting in the cancellation of many cultural activities in the season. In spite of these difficulties, some of the groups staged their works as part of a smaller festival: they performed to sold-out audiences, offering a variety of challenging and innovative pieces to enthusiastic Jerusalem spectators.

The festival traditionally opens with Israeli performances. On November 23, The Department of Theatre Studies from the Hebrew University presented Shakespearean Legends, and "Parking-Lot Theatre" featured The Other Side's Story.

The Théâtre Universitaire Royal de Liège, Belgium, offered a vibrant and hilarious adaptation of a carnival game by Hans Sacks (1553) at the "Ma'abada Theatre," entitled Si tum'aimes. This festnachtspiel, originally called DerTodt Mann (The Dead Man), has been performed in Germany since the sixteenth century.

From Latin America, "El Callejón del Agua," a professional group from Quito, Ecuador, performed La noche de los tulipanes on November 24. Founded in 1990, this company has developed an ambitious theatrical repertoire that reflects various aspects of Ecuadorian life. Their performances are collaborative and played to a range of audiences in which the stage can function as a space of discussion and reflection. La noche de los tulipanes, directed by Jorge Mateus, was first staged on October 11, 2007 after being performed in Brazil and in Spain. The play addresses the nature of the trauma created by immigration and its effect on the people of Ecuador. Despite its 
regional focus, the play is based on universal themes; it is an allegory for all those who travel surreptitiously to unforeseen destinations.

As Mateus observes in his introductory notes to the program, the world's borders were marked without our participation, and we should be allowed to follow our dreams regardless of these boundaries. The play is presented in a dream-like fashion: five actors glide and dance across the stage by turns. Mateus insists on the importance of dreams unlimited by borders, "porque soñar no cuesta nada." In the end, the characters keep hoping but they don't know for sure if what they find is what they were looking for: "Pero ¿dónde estamos? Tengo en la boca el sabor de las algas...Tal vez esta es la patria que buscábamos."

"Teatrotaller," founded in 1993 by a group of talented students at Cornell University, promotes Spanish, Latin American, and Latino cultures

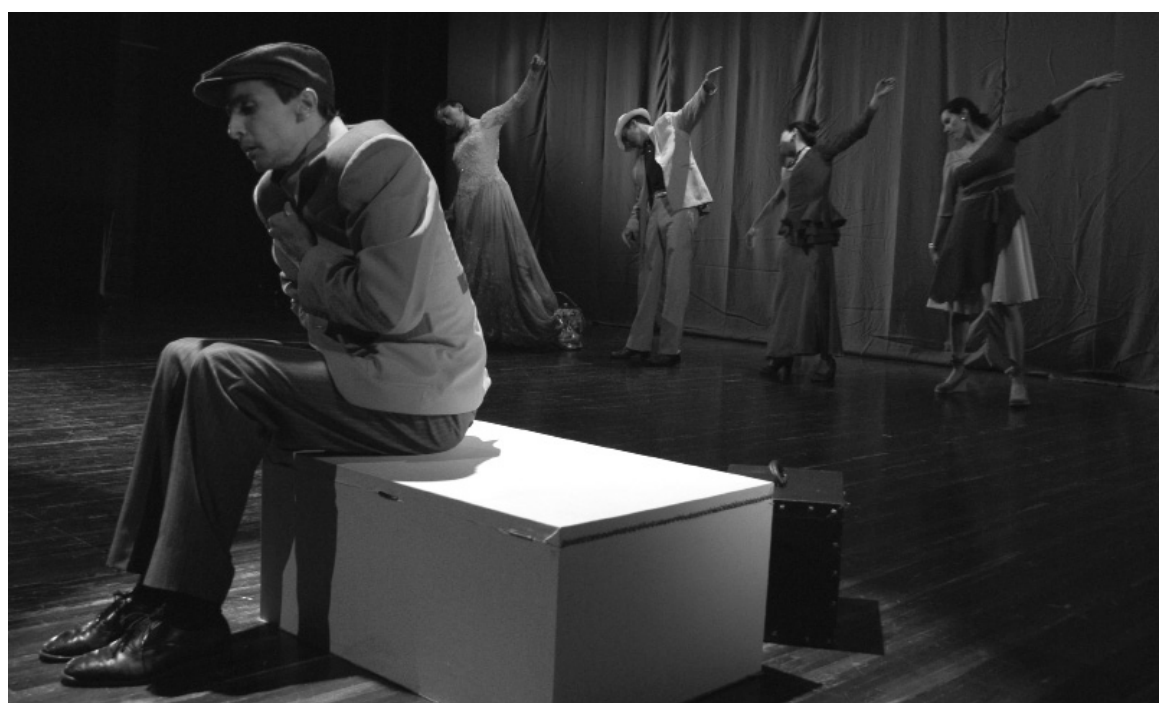

La noche de los tulipanes. Photo: Jorge Mateus

through theatre. This was the troupe's debut in Israel. In 2000 and in 2001 they produced Nora Glickman's A Certain Raquel at festivals in Europe and Latin America. On November $26^{\text {th }}$, Jimmy A. Noriega directed two pieces by Glickman at the "Khan Theatre" in Jerusalem: With Mothers Like These consists of three confessional monologues based on mothers who mean well for their children, but whose actions lead to devastating results:

Mireille is about a mother who tries to protect her son by destroying the invaluable artwork he has stolen. Fanny is based on the true story of novel- 
ist Irene Nemirovsky and the aftermath of her death in Auschwitz. Irene's mother, Fanny, justifies her refusal to take in her grandchildren when they are rescued them from the Nazis, and sends them to an orphanage instead. She now grapples with the memory of her daughter and the guilt associated with her actions. For these monologues Noriega effectively divided the stage in two sections and had each actress alternate her lines with the other, without subtracting from the original texts.

Lot's Wife, the third monologue in this series, recounts the Biblical tale from the perspective of the ill-fated character who was turned into a pillar of salt. As the frozen body of Lot's wife slowly comes to life, awakened by ogling tourists, she feels compelled to share her guilt for having trusted her incestuous husband with her daughters.

Preludes, Glickman's one-act play also featured during this festival, dwells on the interaction among three amateur female musicians, in the 1940s. Bound by shared aspirations and confined by the lack of opportunities, they yearn to escape from their provincial existence through Chopin's music. Their romantic illusions the music inspires, however, soon pose dangerous challenges to their friendship.

\section{Queens College and the Graduate Center}

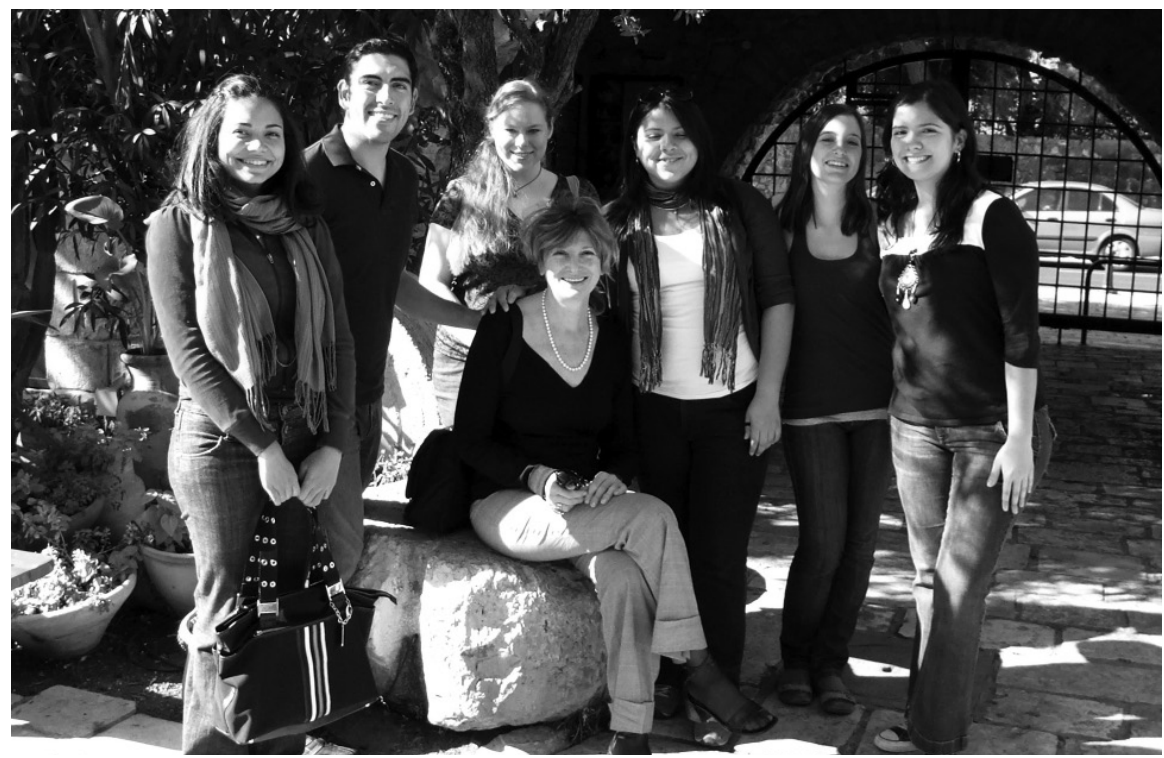

Teatrotaller (Playwright, Director, and Actresses outside Khan Theatre). Photo: Jimmy A. Noriega 
